\section{LATERAL VISION AND ORIENTATION}

To the Editor of Science: Professor C. C. Trowbridge furnished an illuminating paper, printed in ScIEnce September 29, on "The Importance of Lateral Vision in its Relation to Orientation."

In dealing with the question of the process used by man, with his binocular frontal vision, in estimating distances to objects that come within his observation, Professor Trowbridge says:

It is a well-established principle that binocular vision gives to human beings a means of determining the relative distances between near-by objects, as well as the distances of these objects from the observer. The basis of this power lies in seeing the objects from two points of view, giving a stereoscopic effect, which, however, is decreasingly effective as the objects are removed from the eyes. It is apparently partly the decreasing stereoscopic effect with increasing distance which forms the basis of measurement, and partly a judgment of distance in some way through the muscular movements of the eyes, and those governing the accommodation of the lenses. . . .

From the above quotation it appears to the writer that Professor Trowbridge has missed the fundamental principle of estimating distances to observed objects by human binocular vision. If the writer's view or theory is correct, when a man estimates such distances by his vision, he unconsciously performs a trigonometrical operation, in which the distance between the pupils of the eyes is the base of a triangle, the two lines of vision from the pupils, converging in the observed object, being the other sides of the triangle.

The same principle is used by the "rangefinder" on a ship of war, who has a rod about ten feet long as the base of his triangle, from each end of which is measured the angular inclination of the two lines converging in the target, five or ten miles distant. The "binocular" observer has a base two and a half or three inches long, for objects a few hundred feet distant and less. The range-finder makes accurate calculations based on measurements; while the "binocular" observer, from long practise, acquires a sort of "rule of thumb" facility in making such estimates with more or less approximate accuracy, which operation from long habit is performed intuitively and without conscious mental effort.

A man with only one eye, or with defective vision in one of his eyes, finds a difficulty in estimating the correct distance to an object which he extends his hand to grasp; or when inserting a key in a keyhole he must sometimes aid his vision by the touch of a finger to locate the keyhole.

It follows of course that a man with only one eye is without the power to invoke the principle of trigonometry in the estimating of distances to observed objects.

If the above theory is unsound the writer will be glad to have further enlightenment on the question discussed.

$$
\text { T. G. Dabney }
$$

\section{A COMMON, BUT INCORRECT, STATEMEN' CONCERNING THE NUMBER OF BACTERIA IN MILK}

THE literature discussing sanitary milk problems is full of statements like this: "Certified milk is not allowed to have more than 10,000 bacteria per c.c."; or "Grade A milk should not have over 60,000 bacteria per c.c."; and many other similar statements specifying the number of bacteria per c.c. in milk of various grades. These counts are commonly made by the standard agar plate method recommended by the American Public Health Association.

A perusal of a number of bacteriological text-books by American authors shows a general recognition of the fact that these counts are probably counts of groups of bacteria rather than of individual bacteria and that they are probably always lower than they should be because of the fact that not all bacteria will grow on nutrient agar at the incubation temperature used. In spite of these qualifications specifically stated in the majority of these text-books, their authors ignore them in all subsequent discussions and accept agar plate counts as showing the number of bacteria per c.c. Occasionally in these books or elsewhere in bacteriological literature, one even finds the bald assertion that each colony 
on an agar plate develops from a single bacterium.

The development of microscopical methods of counting bacteria in milk have now made it possible to check up this matter. Studies at the N. Y. Agricultural Experiment Station by J. D. Brew, as well as cooperative analyses carried out by the dairy husbandry department of the N. Y. State College of Agriculture at Ithaca and the bacteriological department of the Agricultural Experiment Station at Geneva have shown that the number of bacteria in market milk is rarely less than twice the number of colonies developing on agar plates even after prolonged incubation at two different temperatures; and that the number of bacteria is usually from three to six times the number of colonies. In those fairly common market milk samples where the predominant bacterial flora consist of long chain streptococci, the actual number of bacteria present may be fifteen to twenty-five times the number of colonies on agar plates.

With these facts established, there seems to be no justification for continuing the present unscientific custom of referring to agarplate counts as showing the number of bacteria in milk. As a matter of fact they show the number of colonies developing on nutrient agar (or other culture medium) under the conditions of incubation used, and nothing more. In the earlier literature the latter form of expression was common and is still used by some investigators. Americans, however, generally use the inaccurate form of expression especially when discussing sanitary milk problems.

It does not require a vivid imagination to picture the dismay of the layman, whether consumer, milk dealer or farmer, when he discovers that what he has been told about the number of bacteria in milk is all based on a fallacy and that the real numbers are from one and a half to twenty-five or more times the figures which have been given to him. Neither does it require a vivid imagination to predict that those forces which find it to their advantage to resist the efforts which are being made to control our milk supplies will be quick to seize upon the seeming inconsistencies of bacteriologists as a means of discrediting the use of bacterial counts for controlling milk supplies.

So long as there was no available method by which the actual number of bacteria in milk could be counted, the use of the short form of expression had some excuse because of its convenience. Now that the real facts are known, its continued use will increase the present confusion. This confusion does not trouble bacteriologists, nor will it do so, for the majority of them have understood all of the time that they were probably not telling the truth about the matter; but it does bewilder the uninitiated.

\section{RoBert S. Breed \\ N. Y. Agricultural Experiment Station}

\section{OSTWALD'S HANDBOOK OF COLLOIDAL CHEMISTRY}

IN a criticism ${ }^{1}$ of my review ${ }^{2}$ of Professor Fisher's translation of Wo. Ostwald's "Handbook of Colloidal Chemistry" Professor Richard C. Tolman disagrees with my statements concerning negative surface tension, and submits certain thermodynamic considerations and experiments as evidence of the existence of negative surface tension. The question is one over which two people may disagree inasmuch as it depends solely on their point of view. Professor Tolman relies principally upon thermodynamic considerations, while I refuse to consider energetics as infallible in the present case, but base my reasoning on ordinary atomistics. In fact I regard the application of thermodynamics to disperse systems as decidedly hazardous.

In the first place it is well known (Maxwell) (Smoluchowski) that the second law is no longer valid when applied to particles approaching molecular dimensions. Secondly the first characteristic of all colloidal solutions is unstability. I have yet to experience an absolutely stable permanent colloidal solution. Once we admit the absence of true thermo-

\footnotetext{
1 SCIENCE, 44, 565, 1916.
}

2 ScIENCe, 43, 747, 1916. 